pride of the teacher, and that's the sort of thing I think Dave has done superlatively. Just tonight, for example, I heard of how he went out to Aberdeen, South Dakota, to help one of his former students achieve approval of a residency in dental public health out in what some would call the boondocks, not your usual academic institution.

Today, Dave still gets an enormous number of telephone calls and letters from people all over the world because, when they need help and advice, it seems only natural to them to turn to Dr. Striffler. That must be a source of great satisfaction to him, as it is to the rest of us.
People have characterized Dave as having an iron hand in a velvet glove. In fact, it ought to be other way around, because Dave Striffler is basically a softie-everyone knows he's a soft touch. He is intensely loyal, stands up for people, and is always ready to help. The kinds of things he has accomplished bring credit to The University of Michigan School of Public Health, to the dental profession, to the Dental Health Section of APHA, to all of us here, and in the last analysis to Dave Striffler, himself.

I ask you to join me in saluting this year's John W. Knutson awardee, Dr. David Frank Striffler.

\title{
Response to Receiving the John W. Knutson Distinguished Service Award in Dental Public Health
}

\author{
David F. Striffler, DDS, MPH \\ Professor, Program in Dental Public Health \\ Chairman, Department of Community Health Programs \\ School of Public Health \\ Professor of Dentistry (Community Dentistry) \\ School of Dentistry \\ The University of Michigan \\ Ann Arbor, Ml 48109-2029
}

Thank you Dean Wegman, and thank you Dr. McCune, and a special thanks to the officers and members of the Dental Health Section of the American Public Health Association, including you Michigan alums. In preparing for this session, I first searched my memory and then old volumes of the American Journal of Public Health to help me remember just when it was I first became conscious, if you will, that there was an American Public Health Association and that there was a Dental Health Section. Oddly enough, my bound volumes of the Journal, my personal volumes, go back to 1954-exactly three decades. Prior to that, I can remember attending a meeting of the Michigan Public Health Association in Grand Rapids, Michigan, in 1952, when I also visited the water treatment plant there to see how this fluoridation business worked. At the same visit to Grand Rapids, I attended my first meeting of a group of antifluoridationists, which a local chiropractor had organized. I thought I had sneaked into the meeting unobtrusively and was surprised to feel a tap on my shoulder and turned around to see the waterworks engineer from Grand Rapids, with whom I had just visited that day. We were both there to find out what this new group of "antis" was all about.

My first American Public Health Association meeting was almost 30 years ago in Kansas City in 1955. To give you a notion of how long ago that was, the best single room at the headquarters hotel, The Muehlebach, was $\$ 13.00-$ you could get by for $\$ 6.50$ at the same hotel, but I couldn't afford to stay there because per diem in the state of New Mexico was $\$ 7.00$. I had hitchhiked a ride in from Santa Fe, New Mexico, with a health educator colleague from the state tuberculosis association. We had saved money by driving straight through, alternating driving. The outstanding memory of that meeting was the opportunity to hear Harry Truman give the keynote address at the Lasker Awards presentations in the Music Hall. ("Give-'em-hell Harry" by that time had retired to nearby Independence, Missouri.) It was a standing-room-only crowd.

I went to that APHA meeting, I suspect, simply because I had been invited to be a discussant at one of the sessions. Why I went certainly provides a hint to those of you trying to increase the membership in this section. I remember well having the good fortune of being invited to Phil Blackerby's hotel room-Phil then was the dental director of the W. K. Kellogg Foundation-to discuss a project in New Mexico I had written him about. Little did I know that Frederick S. McKay and John Knutson would be there in the same room sipping some Tennessee mash squeezings and branch water. I was truly impressed by Dr. McKay, a fine distinguished gentleman who just three years previously with Trendley Dean had been awarded the coveted 


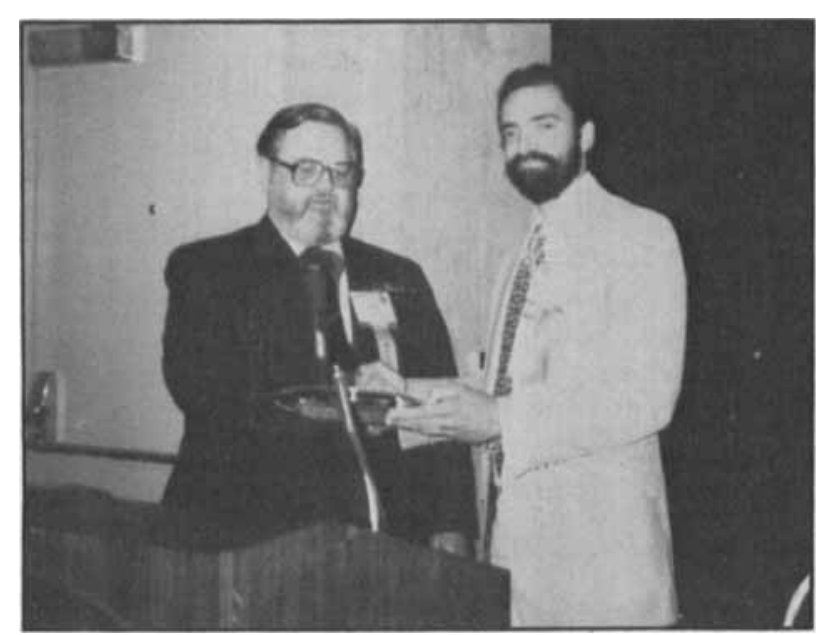

Dr. David Striffler, recipient of the 1984 Knutson Award (left), and Dr. Caswell Evans, Jr., Chair, Dental Health Section, APHA

Lasker Award of the American Public Health Association-to my knowledge those are the only two dentists ever to have won that award. Bob Downs of Colorado was the section chair that year and Carl Sebelius was the section secretary.

The next year the meeting was in Atlantic City. I didn't know how I was going to get there, but somehow I did. John Fulton of the Children's Bureau was the chairman, Don Galagan had been nominated for section secretary, and I was surprised to find myself nominated for the vice-chairmanship. Only in the outfit for two years and you find yourself nominated for office. It shows you what a real competitive outfit it was in those days. That 1956 meeting stands out because I, Jack Pelton, and Goldie Krantz were on the program. Those of you from the West Coast remember Goldie, then of the ILWU-PMA Welfare Fund, the International Longshoremen and Warehousemen's Union-Pacific Maritime Association-there, I got that acronym right-or more correctly, initialism. They and Nate Sinai were discussing prepaid dental care-the first time I had ever heard dental insurance even mentioned in any kind of formal meeting. Dental insurance? What was that? I also had an opportunity to meet Albert Russell and to talk with him about periodontal indexes. We were both pleased to find that we both had had trouble applying the new P-M-A gingivitis index of Massler and in getting any kind of consistent results. We also discussed a periodontal index that he was just testing then-this was 1956 and I think we call it the PI now. Just evidence of another good reason for attending these meetings: the learning, the discussion, and the interchange that goes on both formally and informally.

In any event, I think I attended every APHA meeting for the next decade or so as I worked my way through the chairs-falling back from vicechairman to section secretary and working my way up to vice chairman again and then chairman. All this historical meandering does have a purpose and that is to point up what $I$, personally, gained from APHA, from the Dental Health Section, and from my contacts with others in APHA. Serving as section secretary got me invited to New York City where I'd never been before, at least as an adult. The APHA program planning meetings were held in New York where the APHA headquarters was then located. During those program planning meetings we thrashed out the annual program for the entire Association for the next annual meeting. I had the opportunity to meet some fine people who were representing their sections and working out various compromises in joint sessions with them-true interdisciplinary interaction. Among those fine people was Bill Gibson; you'll remember him, Myron [Wegman]. When I met him, he was section secretary of the Environmental Health Section and later was to become Acting Dean at the University of Michigan. I also met a fellow named Hugh Leavell when I was on the Resolutions Committee. That committee preceded any kind of reference committees. It just was the committee that heard the resolutions that had been submitted and then recommended them on to the Governing Council. I learned a lot about puns from Hugh Leavell. I enjoyed meeting him; it was most educational. In those days at the close of the annual meeting there was a Friday luncheon at which the editorial board met with the section officers. Each group discussed the papers that were presented and which ones might be recommended for high priority for immediate publication by the American Journal of Public Health. At that time the journal's editor was George Rosen, and I think we were able to get a dental paper published about once every six months. Somehow we had to break this hold, and I'm glad to see we had one whole issue recently devoted just to dentistry. Thanks to Myron Allukian, I suspect.

During the $50 \mathrm{~s}$ and 60 s there seemed to be a constant battle going on between the Dental Health Section of APHA and the then American Association of Public Health Dentists for primacy in the public health dentistry field. When one was up the other seemed to be down-if not in membership then in the quality of the program or leadership. There was a real problem for salaried dental public health folks to get to more than one out-of-state meeting a year-if they were lucky enough to get to even one. Governors in those days, as now I suspect, attempted to gain popularity by cutting off travel funds and "keeping those bureaucrats at home." The Dental Health Section had suffered because getting to APHA when you were working in a general public health agency, or a school of public health for that matter, was difficult because everybody else also wanted to go to APHA-you had a better chance of getting to your own basic discipline's meeting. Serious consideration was given in those days to combining the membership 
of both AAPHD and the Dental Health Section and at the least to combining the publications and mailing lists. "What goes around comes around." The Newsletter of the Dental Health Section of APHA was then a sporadic, fitful effort at best, and the Journal of Public Health Dentistry was having trouble finding an editor, a publisher, and financing. A coalescence never took place, probably because AAPHD then insisted on restricting its membership to dentists. Maybe on Wednesday in the session Jean Frazier has put together we can talk once again about building a coalition.

As I think back to the people who have received this Knutson award ahead of me, I was and still am quite truly shocked and surprised that I should have been considered-and I mean that quite seriously. As a youngster in this field, I admired David Ast-he's sitting right there in the third row-I admired him tremendously and was delighted when the Dental Health Section honored him as the first recipient. I had the pleasure of nominating him for honorary membership in Delta Chapter of Delta Omega, the public health honorary society. His splendid record in New York State with the Newburgh-Kingston fluoridation study, his pioneering work in providing orthodontic services for handicapped children-you mean a public agency's providing orthodontic services, my goodness - and in many other arenas need not be recounted here, but Dave, they were many and I admired you from afar and still do.

The second distinguished recipient, Jim Dunning, sitting right there in the second row, I was also pleased to see named. As I grew acquainted with Jim over the years I watched him consistently ask the most piercing and penetrating questions at meetings of this section, and I came to admire him. I have always admired his steadfast loyalty to the promotion of the dental nurse concept as it might be applied to the United States - a concept that he turned me around on completely - he probably doesn't know this-because my early orientation had been to oppose it. It was his 1957 paper in Cleveland before this Dental Health Section that did it. I also was impressed, when I, as an examining member of the American Board of Dental Public Health, saw Jim Dunning, a senior distinguished dental public health professional, a Harvard professor, with no quarter asked, no special favors, apply for and be admitted for examination by the board. He defended his projects and wrote the examination right alongside some of his own students-and he did beautifully. Now that's the mark of a man--or a woman or a human being. I am honored to be in his company.

And that same 1957 was the year that John W. Knutson became the first dentist to be president of the American Public Health Association. It's his name that is attached to this award, you'll recall. That year the ADA brass turned out in force and threw a presidential reception in his honor. Can you imagine their doing that now? John broke considerable new ground of significance to this audience. If I am correct, he was the first in PHS to employ a public health dental hygienist-Elizabeth Warner now Waggener-in 1951. He also employed behavioral scientists in the old Division of Dental Public Health, again in the 50s. My first direct contact with John Knutson was two years earlier, when he examined me in his role as an examining member of the American Board of Dental Public Health-a specialty board of dentistry of which incidentally this section was an original sponsor-no longer a sponsor, but an original sponsor. You can begin to see I would indeed be shocked to think that my name might be placed in such distinguished company. Psychologists call it the "impostor phenomenon," or so I understand. Although I may feel out of place, that I'm imposing, that I'm an impostor, I am not going to refuse the award. I accept it with gratitude and, I trust, appropriate humility. Thank you. 